\title{
Strategies for Governing: An Approach to Public Management Research for West and East
}

\begin{abstract}
Alasdair Roberts*
Abstract: Research in Public Management (PM) has run into two obstacles. In Western countries, scholars complain that PM research neglects big questions about the overall design of government and its adaptation to new threats. Meanwhile, Asian scholars complain about the Western-centrism of PM research and its failure to account for the distinctive features of governance in their countries. A new approach to PM research will overcome both obstacles. This new approach assumes that leaders of the world's 195 states face the common challenge of devising a strategy for governing their territory and population that will achieve security, prosperity, and justice. These "strategies for governing" vary between countries and over time, as leaders wrestle with contradictions among goals, uncertainty about tactics, turbulent environmental conditions, and sticky cultural and institutional inheritances. This is a macro approach to PM research that provides a framework for addressing big questions about governance while overcoming the Western-centric bias of current scholarship.
\end{abstract}

Keywords: governance, strategy, public administration, public management

\section{TWO PROBLEMS, ONE SOLUTION}

The scholarly enterprise known as Public Management (PM) has thrived for forty years but now confronts two obstacles to continued progress. One of these obstacles is perceived mainly in the West; the other, mainly in the East. Fortunately, the two obstacles can be overcome in the same way. PM researchers must learn how to study the fundamental problems that are faced by leaders of all states, and the

\footnotetext{
* Alasdair Roberts is a professor of political science and public policy, and director of the School of Public Policy, at the University of Massachusetts Amherst. Email: asroberts@ umass.edu.
}

Manuscript received January 17, 2018; out for review January 30, 2018; review completed February 24, 2018; accepted March 1, 2018.

The Korean Journal of Policy Studies, Vol. 33, No. 1 (2018), pp. 33-56.

(C) 2018 by the GSPA, Seoul National University 
diversity of strategies for governing (SFGs) that are crafted by leaders to manage those problems.

For decades, PM research has been dominated by scholars in the United States and a few other Western democracies, and has focused mainly on the improvement of efficiency or performance within public agencies (Hou, Ni et al. 2011, pp. i47i48; Walker 2011, p. i56; Haque and Turner 2013, p. 244; Juliani and de Oliveira 2016, p. 1036). This research responded to a crisis of legitimacy in advanced democracies in the late twentieth century that was manifested in public demands for spending reductions and tax cuts (Lynn Jr. 2006, p. 104; Pollitt and Bouckaert 2011, p. 6). As Owen Hughes has observed, "governments were faced with declining real revenue [and] political demands to maintain services at the same levels. In these circumstances, the only avenue was to improve productivity" (Hughes 2003, p. 51). Policymakers and PM scholars were preoccupied with making public agencies "work better and cost less" (Gore 1993).

Over the last decade, many Western scholars have questioned this focus on agency-level performance. They observe that Western governments are buffeted by powerful forces, such as the resurgence of terrorism and great power tensions, climate change, advances in information technology, mass migration, rising populism, and deepening societal divisions. PM researchers have struggled to make sense of these broad trends and give advice on how they should be dealt with. The decades-long focus on agency-level performance has created a gap in analytic capabilities: research on "big questions" about the overall design of government, and its adaptation to changing conditions, has been discredited for many years, and the theoretical equipment for addressing such questions has been abandoned (Milward, Jensen et al. 2016; Peters and Pierre 2016; Pollitt 2016).

Scholars outside the developed West have different complaints about PM research. Some have charged Western scholars with ethnocentrism and parochialism (Fitzpatrick, Goggin et al. 2011, p. 827; Hou, Ni et al. 2011, p. i46). Many Asian scholars resisted the "global paradigm" for public management that was promoted in the 1990s and early 2000s because it reflected the priorities of Western rather than non-Western states. They observed how Western-style reforms often failed because they were "not compatible with the inherent political, social, and cultural institutions of developing countries" (Ho and Im 2015, p. 276). Asian scholars have called for a true global dialogue in which the distinctive challenges of non-Western countries are acknowledged (Gulrajani and Moloney 2012, p. 85; Haque and Turner 2013).

In sum, PM research has hit two roadblocks, one in the West and one in the East. A new approach to research provides a way around both. It provides scholars with tools for investigating big questions, as Western critics would like to do. And it 
makes room for the distinctive circumstances emphasized by Eastern critics. This new approach enables a global dialogue about problems of public administration, while recognizing that the architecture of administration always differs among countries. This approach restores the state as a central concept in the study of public administration. All states have leaders who struggle to invent strategies for governing (SFGs) that will advance goals such as security, prosperity and justice. But national conditions and priorities vary over place and time. Consequently, the content of those strategies - and the architecture of the institutions that give effect to them - also varies between countries, and between generations. An additional aim of PM research should be to understand the processes by which SFGs are formed and to assess their merits.

\section{RECOGNIZING STATES}

The SFG approach adds a new level of analysis to PM research. Other disciplines operate at more than one level: there is micro-economics as well as macro-economics, and there are subfields of political science that focus on individuals or communities as well as regimes or countries. But public management has limited its range over the last forty years, focusing mainly on agencies, networks of agencies, or programs within agencies - that is, on the meso-level of government. There is also an initiative to concentrate more narrowly on "the micro-perspective of individual behavior" (Tummers, Olsen et al. 2016, p. 1). There is no counterweight to this emphasis on meso- and micro-levels, no systematic form of macro-research, as there is in other fields. This was not always the case. Until the $1950 \mathrm{~s}$, researchers in American public administration routinely operated at a higher level as well, invoking the state as a central concept in their work (Roberts 2018, pp. 2-3). Progress in $\mathrm{PM}$ research requires that we revive the state as a core concept.

Many PM researchers balk at this proposition because of mistaken understandings about research involving the state. In the nineteenth century, intellectuals who wrote about the state often romanticized it as well. They were proponents of statism, a political philosophy hostile to democracy and minority rights (Neumann 1950, pp. 15-16). Many of these intellectuals worked within the tradition of continental European philosophy, and were not preoccupied with testing hypotheses rigorously, as Anglo-American positivists were (Critchley 2001, pp. 111-122). As a result, talk about the state was sometimes associated with illiberal and sloppy thinking (Friedrich 1940, p. 343). But this is not a necessary association. There are areas of scholarship and practice in which the concept of the state is applied with care. For example, 
international law is absorbed with defining the elements of statehood. Every state must develop criteria for identifying other states with which it is prepared to establish diplomatic relations. The United Nations and other international organizations must make an exact count of states so that they know how many seats to place in their meeting halls. Much research in political science and international relations has been dedicated to the careful description of states. Furthermore, many of these states are consolidated liberal democracies that reject statism. Most Americans oppose statism while acknowledging the existence of an American state: they pledge allegiance to its flag, sing its anthem, respect its laws, and pay its taxes.

The state is the fundamental unit of political organization in the modern world. In other disciplines, this is taken for granted. Political scientists regard the state as "the natural container of politics" (Goodhart 2011, pp. 49-50) while sociologists say that it is "the pre-eminent power-container of the modern era" (Giddens 2013, p. 120). For specialists in international relations, the state is "the primary unit of political aggregation in world affairs" (Sobel 2013); for political geographers, "the basic building block of the world political map" (Painter and Jeffrey 2009, p. 20); for international lawyers, the "primary unit of political and economic organization" (Lowe 2015, p. 4).

The sociologist Max Weber defined the state as "a human community that successfully claims the monopoly of the legitimate use of physical force within a given territory" (Weber 1946, p. 78). This definition is imperfect. States never achieve a complete monopoly on the use of force. Under international law, it is enough to gain "effective control" of territory (Crawford 2006, Chapter 2). Weber's reference to the legitimate use of force also creates difficulties. We can put that aside for the moment. This leaves a hard bottom line: one prerequisite for existence as a state is the capacity of authorities to suppress major rivals within well-defined borders.

Another approach to the definition of a state emphasizes its composition as well as to the tasks that it must perform. John Hall and John Ikenberry have defined the state as "a set of institutions" that maintain authority within a territory (Hall and Ikenberry 1989, pp. 1-2). Other scholars describe the state as a "complex" or "ensemble" of institutions that jointly exercise supreme authority within a territory (Hay and Lister 2006, 5; Jessop 2016, p. 49). Similarly, Theda Skocpol defines the state as "a set of administrative, policing, and military organizations headed, and more or less well coordinated by, an executive authority" (Skocpol 1979, p. 29). This approach to definition, which emphasizes the way in which the state is constituted, can be modified in two ways. Institutions consist of people who fill roles and execute routines. It is a friendly amendment, therefore, to define the state not just as an institutional complex that performs certain tasks, but also as the group of people 
who populate those institutions and share responsibility for those tasks. Similarly, these people must have a shared understanding of what those institutions are trying to do and how they are supposed to work. The substance of the state consists not just of institutions and people, but also this shared culture.

States have another critical feature. They possess a status or standing, which is referred to as statehood. The conferral of this status is the final step in transforming an institutional complex into a state. Not only must an institutional complex wield authority as a matter of fact; its right to exercise authority must be recognized by other actors. The most critical form of recognition comes from other states and is guided by principles of international law (Crawford 2006, Chapter 1; Shaw 2008, Chapter 5). An institutional complex that wins this recognition is less likely to be attacked by other states and is free to engage in diplomacy and join international organizations. Similarly, the authority of this institutional complex needs to be accepted by the governed population. This is usually what we mean when we talk about legitimacy. People within a territory must also acknowledge that an institutional complex has the right to rule. There is a practical reason why this is essential. States cannot govern through the use of force alone: leaders depend on "habitual obedience of the bulk of the population" (Lauterpacht 1947, p. 28).

\section{LEADERS, GOALS, STRATEGIES, AND INSTITUTIONS}

The SFG approach relies on other concepts as well. For example, it recognizes that all states have leaders. By this we mean the group of people within state institutions who have the greatest control over the ways in which state power is exercised. Sometimes we refer to these people as rulers, especially when talking about non-democratic states such as China and Russia. In the United States and other democracies, softer language has been preferred: we talk about policymakers or decision-makers instead. Whatever the terminology, we have the same underlying idea in mind. We are interested in people who occupy the "pivotal positions" and "strategic command posts" within the institutional complex that constitutes the state (Mills 1999), and "exert active power" over definition of major priorities and the means by which they will be pursued (Laski 1919, p. 27).

We can define the set of goals with which leaders are mainly concerned. Indeed, it was once taken for granted that the study of public administration was impossible without identifying these goals. In 1939, Leonard White enumerated "the ultimate ends of the state ... [which are] the maintenance of peace and order, instruction of the young, equalization of opportunity, protection against disease and insecurity, 
[and] adjustment and compromise of conflicting groups and interests" (White 1939, p. 7). And Charles Merriam described the "ends of government" in 1944: "(1) external security, (2) internal order, (3) justice, (4) general welfare, and (5) freedom" (Merriam 1944, p. 21). Talk about the "ends of the state" fell out of fashion in public administration after the 1950s but continues today in other quarters. Since the late 1990s a new scholarly field known as Statebuilding has emerged, with the aim of giving advice about the design and consolidation of public institutions in war-torn and fragile states. Experts working in this new field are explicit about state goals. One influential text identifies ten key "functions of the state," ranging from public order to protection of citizenship rights (Ghani and Lockhart 2008, Chapter 7).

When we enumerate state goals, we must sometimes think as realists. For example, we should expect that leaders will try to maintain their own position within the state apparatus. This assumption is a staple of analysis in political science: "[S]urvival in office is ... the essence of politics ... [A]ll actions taken by political leaders are intended by them to be compatible with their desire to retain power" (Bueno de Mesquita 2003, pp. 8-9). Of course, we can question whether this ought to be a primary goal of state policy, and we will see that it also conflicts with other goals, such as advancement of the basic human right to self-government.

A second goal is to increase the power and legitimacy of state institutions within the territory claimed by the state. To a point, this is a matter of necessity. As we noted, one of the prerequisites for state recognition is effective control of territory (Crawford 2006, p. 58). Of course, effective control cannot be achieved through the use of force alone. Eventually, people must accept that compliance with directives is the right thing to do. Cultivating popular legitimacy is therefore an important part of the project of establishing authority. There are many ways of cultivating public support: by stoking fear about disorder or nationalist pride, offering guarantees about the rule of law or elections, devolving power to lower tiers of government, or providing money and services.

A third goal is the extension of power and legitimacy within the state system. Leaders build up military capacity and economic clout so they can repulse external threats, forge alliances, and assure access to critical resources and markets. Legitimacy within the state system is mainly expressed through recognition by other states. There is also a less tangible form of inter-state legitimacy that is captured in the concept of "soft power" - the capacity of one state to obtain the cooperation of other states because of the appeal of its policies and way of life (Nye 2011, Chapter 4).

A fourth goal is the increase of national income and wealth (Im 2016, pp. 8-9). Economic growth helps leaders in several ways. Prosperous societies are easier to 
govern: citizens are happier, factional conflict is less intense, and unrest can be quelled by payments from the state. A larger economy also means more tax revenue to pay for security and other public services. At the same time, prosperity increases influence within the society of states. Leaders are in a better position to recruit allies by providing aid, and other states have a stronger motivation to negotiate for market access.

A fifth goal for leaders is the advancement of human rights. To some degree, this is also a matter of self-interest for leaders. States that abuse their population might be excluded from international organizations and attacked by other states. A reputation for cruelty also undermines soft power abroad and legitimacy at home. But the self-interest of leaders is a weak guarantor of human rights: it may discourage outright abuses, but not much more. When we talk about the advancement of human rights, we are mainly talking about a goal that leaders ought to pursue, regardless of their inclinations. Indeed, the pursuit of human rights sometimes requires leaders to put aside other goals. For example, the United Nations Declaration of Human Rights says that leaders should be selected through free elections, which collides with the ambition to survive in office (Donnelly 2013, Chapter 13).

Leaders of states develop an overall view about the relative importance of these goals and methods of pursuing them. We can call this their strategy for governing (SFG). SFGs are not formal plans and they are not always fully articulated. Large parts of an SFG are simply taken for granted, as part of the generally accepted way of dealing with national problems. Sometimes the content of strategies must be inferred from the behavior of leaders. Strategies range in quality: they may be incoherent, inconsistent, or ineffective.

Governance strategies also vary between countries and over time. For example, American leaders since World War II have generally preferred a strategy that emphasizes federalized government, separation of powers, popular elections, constitutionalized protection of basic rights, free-market capitalism, a powerful military apparatus, and leadership in international diplomacy. This has been called the "American way of government" (De Grazia 1957). By contrast, modern-day Chinese leaders pursue a different strategy, sometimes called the "China model" (Bell 2015). It rejects federalization, separation of powers, free elections, strong protections for individual rights, and loosely regulated markets, on the premise that these policies will undermine governmental effectiveness and social stability. American and Chinese leaders are equally convinced about the robustness of their strategies. But neither strategy is rigid: on the contrary, they are constantly changing. The "American way of government" was different before the election of President Ronald Reagan, while the "China model" was different under Chairman Mao Zedong. 
The SFG concept is related to that of grand strategy, which is applied in the fields of International Relations and Security Studies (Milevski 2016, p. 1). The concept of grand strategy was introduced in the nineteenth century to describe an overall policy on the use of armed forces. The intention was to distinguish between "the large, broad plan for winning a whole war on several fronts ... [and] the localized strategy of the commander of a single army" (Barrows 1942, p. 207). The era of total war (1914 to 1945) led military thinkers to expand the concept. In 1943, Edward Mead Earle defined grand strategy as "the art of controlling and utilizing the resources of a nation ... [so] that its vital interests shall be effectively promoted against enemies" (Earle 1943, p. viii). The concept was revived and expanded again in the 1980s by two historians, Paul Kennedy and John Lewis Gaddis (Kulman 2016). Kennedy said that grand strategy was concerned with the "husbanding of national resources" so that a state could defend itself in "an anarchic and often threatening international order" (Kennedy 1991, pp. 4-6). Other scholars have stretched the concept of grand strategy even further. Hal Brand defines it simply as an "intellectual architecture ... [that provides] a purposeful and coherent set of ideas about what a nation seeks to accomplish in the world, and how it should go about doing so" (Brands 2014, pp. 2-3). Similarly, Peter Trubowitz has argued that grand strategy, "the broadest level of foreign policy," can be focused on many objectives: security, power, wealth, national honor, and the leaders' own hold on executive power (Trubowitz 2011, pp. 1 and 9).

A difficulty with these broader conceptions of grand strategy is that they are still limited to the design of foreign policy. They exclude domestic affairs. But this is an artificial restriction. In practice, leaders do not have one strategy for managing foreign affairs and another for managing internal affairs. Rather, leaders have one overall view about priorities and methods. Some internal policies are adopted to ease problems of foreign affairs, and some external policies are adopted to ease problems of internal control and legitimacy. Everything must fit together, and the label we can give to this overall plan is the strategy for governing.

Leaders give effect to SFGs by building and renovating institutions (Huntington 1968, p. 12; March and Olsen 1989, p. 160; North 1990, p. 3; Mahoney and Thelen 2010 , p. 4). In other words, the institutional complex that constitutes a state can also be regarded as the expression of an SFG. One immediate objection might be that institutional complexes are built up over decades, and even centuries. It seems unreasonable, therefore, to describe any complex as the expression of strategy of the current generation of leaders. This is a fair criticism. The state might be more accurately described as an accretion of institutions that have been established at different points in time in an effort to implement a succession of governance strategies. Most 
of this complex is taken for granted by the current generation of leaders. Leaders adjust existing institutions rather than attempting a root-and-branch overhaul. They concentrate their rhetoric and reform efforts on those parts of the complex where there is a serious mismatch between existing routines and their preferred governance strategy.

\section{FIVE CHALLENGES IN STRATEGYMAKING}

The design of SFGs is hard work for five reasons. The first is that goals often collide with one another. It is not easy to achieve national security, internal order, prosperity and justice at the same time. Achieving national security might require taxes and conscription, which could undermine economic growth and internal order. Prosperity might be improved by reducing border controls with other countries, but this could undermine national security. Achieving internal order might mean tougher policing or surveillance, which could undermine civil liberties. We could go on. Pervasive goal conflict forces leaders to set priorities and search for clever ways of minimizing trade-offs.

A second challenge in strategy-making is technical uncertainty. Even if leaders are settled on priorities, they cannot be sure which course of action will achieve those priorities most directly (Hult and Walcott 1990, p. 51). Technical uncertainty arises because leaders have limited mastery over their environment. Often, they lack information about social and economic systems within their territory, and tools to influence these systems. Their capacity to influence other states may be even more constrained. Because of these shortfalls in information and ability to influence, leaders can never be certain about the effects of their actions. The most thoroughly considered choice of tactics is still a gamble (Kissinger 1961, p. 355).

A third challenge for leaders is turbulence in the environment. Their difficulty is not only that social and economic systems are vast, complex, and hard to understand. In addition, these systems change constantly (Farazmand 2009, p. 1007). Patterns of human fertility, mortality, and settlement are never settled, and neither is popular culture, or the character of major societal cleavages (Melosi 2001, p. 130; Cannadine 2014). The structure of industries and markets is similarly unstable, while key technologies also change rapidly (Schumpeter 1976, Chapter 7). And in the domain of international affairs, great powers "come and go, they rise and fall" (Lundestad 2017, p. 1). Even factors that we have sometimes taken for granted, such as climate, have proved to be changeable (Maslin 2014). Such turbulence makes any governance strategy obsolete quickly. As circumstances change, so must priorities, 
as new threats arise, and old ones dissipate. Turbulence also makes existing knowledge about the world unreliable, and perhaps also tactics.

A fourth challenge for leaders arises out of constraints on their capacity to absorb and process information. In part, we are talking about the personal qualities of leaders: some are simply more adept in gauging conditions and charting a course. At the same time, leaders are supported by institutions that are supposed to improve executive decision-making by defining and evaluating policy options (Campbell and Szablowski 1979; Porter 1980). These institutions also vary in quality from one country to the next. Recently, governments have struggled to adjust these institutions to a world in which the flow of information and pace of events has accelerated (Barber 2007, pp. 297-300).

A final challenge for leaders has to do with the management of cultural and institutional inheritances (Evans, Rueschemeyer et al. 1985). Leaders never work on a clean slate. Rather, they govern societies in which there are well-established routines for managing everyday interactions. These routines are often "sticky" or hard to change (Fukuyama 2011, p. 16). Even without stickiness, there is only so much change that a generation of leaders can accomplish within its lifetime. Leaders must decide which aspects of the institutional complex are most in need of reform, and which should be left alone. And they must decide how to achieve that reform whether by subtle amendment or a frontal assault on the status quo. In a sense, leaders are gambling once again. If they are too ambitious, and reach too far, they may fail to accomplish any change at all.

We can see from this brief survey of challenges that governance strategies are fragile constructions. Often, they are founded on "leaps of faith" rather than solid evidence about likely effectiveness (Macdonald 2014, pp. 197-198). In addition, strategies become outmoded quickly, and so do the institutional complexes that give expression to them. Leaders are caught in a never-ending project of reconsidering strategies and restructuring institutions (Dewey 1927, Chapter 1). Failure to master this project can have catastrophic consequences for public welfare. At the extreme, states may collapse, as many have over the last century, even in the developed world. As Donald Kettl has observed, "Nothing that gets out of sync with its environment lasts long - and that goes for governments just as much as dinosaurs" (Kettl 2016, p. 1). Leaders must be realists, aware that the world is full of threats to essential interests. 


\section{STRATEGYMAKING AND BIG QUESTIONS}

We have surveyed a new approach for thinking about problems of governance and institutional reform, with the aim of overcoming two obstacles in PM research. The first obstacle, identified by critics of PM research in Western countries, is sometimes described in general terms as neglect of the "big picture" or "big questions" in public management. We can specify two underlying concerns more precisely.

One is that researchers have ignored the "large forces" or "big trends" that shape the evolution of government (Roberts 2013; Milward, Jensen et al. 2016, p. 330; Pollitt 2016). These large forces include:

- Changes in human fertility, morbidity and mortality, migration and settlement;

- Shifts in patterns of economic production, commerce, and finance;

- Improvements in physical and social technologies;

- Shifts in power within the international system of states; and

- Alterations in climate and geography.

These "environmental factors" clearly affect decisions about the role and design of government - or about the "capacity and purpose of the state," as Brint Milward puts it (Milward, Jensen et al. 2016, p. 330). But PM researchers are not skilled in studying these factors and explaining how they influence administrative reform priorities (Moynihan 2009; Roberts 2010). Indeed, some PM researchers are unaware of the context-bound character of PM research itself. The problem of context-blindness applies to the future as well as the past. Because the field does not think systematically about environmental factors, it struggles to anticipate new threats to state effectiveness. PM scholars are often caught off-guard by shifts in reform priorities that are caused by events such as the 9/11 attacks or the global financial crisis of 2007-2008 (Roberts 2013, Chapter 1). Or they give short shrift to slower-moving but still consequential phenomena such as migration or climate change (Pollitt 2015).

Critics who worry about big questions are also interested in the processes by which states adapt to changes in their environments. More exactly, they worry that states are failing to respond intelligently to altered circumstances. A considerable literature in other domains, such as political science, expresses concern about the "unsustainability" of the American state as it is presently configured, and about the "dysfunctionality" of government as it confronts new challenges (Jacobs and King 2009; Mann and Ornstein 2013). Francis Fukuyama has even suggested that the American state is decaying, a condition that arises when "institutions prove unable 
to adapt" (Fukuyama 2014, Chapter 36). Similarly, Donald Kettl worries the overall failure of American government to "adapt to the challenges it faces" (Kettl 2016, Chapter 1). PM research has neglected this problem. There is a substantial body of research on organizational change within agencies or offices (Fernandez and Rainey 2006) - again, at the meso-level of government - but little on adaptation of government as a whole.

The SFG approach would address both of these concerns. Any study of governance strategies must begin with an understanding of the overall context confronting leaders, and the ways in which that context changes. Moreover, it requires explicit attention to the ways in which leaders take that context into account as they define and pursue goals. The problem of "intelligent adaptation" is central to the SFG approach.

The SFG approach also addresses other criticisms that are made against PM research. For example, PM research gives short shrift to questions relating to policing, defense and diplomacy. It has largely abandoned the realm of international affairs, and even in the realm of domestic affairs, it focuses disproportionately on social policy and civil administration (Ni, Sugimoto et al. 2017, p. 6). This may again reflect the priorities of Western countries in the 1970s, a time in which a principal concern of leaders was the sustainability of the welfare state (Pollitt and Bouckaert 2011, p. 6). Still, this is a major gap in the PM research agenda. Internal order and external security are the two most basic concerns of leaders. In most countries, the most difficult questions of governance relate to these two subjects.

PM research is also criticized for failing to take a broad view in another sense: by giving short shrift to history (Pollitt 2008, p. 29; Raadschelders 2010, pp. 235 and 241). PM scholarship looks backward for a few years but not much longer. One result is that researchers miss slow-moving but important tendencies in the evolution of government, as well as patterns in crises or shocks. By contrast, the study of SFGs requires a long view. In this respect, the SFG approach emulates scholarship in international relations, which studies the evolution of the international order over decades or centuries (Opello and Rosow 2004; Spruyt 2009, p. 18). This historical sensibility makes it easier to recognize "the broad dynamics (economic, geopolitical, and cultural) that influence contemporary events" (Brands and Suri 2015).

\section{RECOGNIZING DIVERSITY IN STRATEGIES}

While critics in the developed West lament the neglect of big questions, non-Western scholars express other concerns about PM research. They complain 
about the parochialism of PM scholarship, the unthinking attempt to transplant institutional reform projects from West to East, and inattention to the distinctive needs and circumstances of non-Western societies. The charge that PM research has a Western bias is hard to refute. A focus on governance strategies may help to address this complaint.

Begin with complaints about the inappropriate transplantation of Western-style institutional reforms. Pressure on non-Western countries to reform their institutions on Western principles intensified in the 1990s. International organizations like the World Bank and International Monetary Fund promulgated a doctrine about the design of public institutions, sometimes known as the Washington Consensus, which largely reflected Western understandings about good government (Williamson 2000). In 2002, President George W. Bush suggested that this approach to governance was the "single sustainable model for national success" (Executive Office of the President 2002, p. iv). PM researchers encouraged diffusion of the Western template by talking about the emergence of a "global paradigm" for public management which actually reflected the priorities of a handful of Western democracies (Farazmand 2012, p. 497; Pal 2012, Chapter 1).

Much scholarly effort has been dedicated to the question of whether there really has been a "global revolution" in public management. There is doubt about the existence of a common reform agenda even among Western states (Hood 1998, Chapter 9; Lynn Jr. 2006, Chapter 2; Pollitt and Bouckaert 2011, pp. 11-15). Researchers have also questioned how far the western model of public management has been adopted in Asian countries (Cheung 2005; Christensen, Lisheng et al. 2008). We should note that this question also has a Western-centric bias, because it suggests Asian experience is relevant only to the extent that it affirms or rejects hypotheses about "imitation" or "learning" from the West. Still, a common answer is that the Western practices have gained little ground in many countries outside the West (McCourt 2002, p. 234; Cheung and Scott 2003, Chapter 1).

Why is this so? One explanation is that Western reforms are ill-suited to the distinctive needs of Asian societies. For example, Western reformers have been preoccupied with streamlining and deregulating civil services that are already free of corruption, but in many non-Western countries, the priority is to build up civil services and establish the central controls necessary to purge corruption (Shepherd 2003). Similarly, the Western agenda has been concerned with reducing government intervention in mature economies, but in some poorer countries, government must guide economic development through active support of industry and infrastructure (Cheung 2005, pp. 263-264; Chang 2008; Im 2014). Western reformers have also assumed that limiting the role of government will address a crisis of trust among 
ordinary people, but in some non-Western countries there is no comparable crisis of trust, while in others a more likely path to improved trust is by expanding basic services rather than cutbacks (Zhao and $\mathrm{Hu}$ 2017). In addition, Asian scholars have suggested that Western-style reforms could undermine national sovereignty and self-reliance, a crucial consideration for countries escaping from two centuries of Western domination (Haque 2002, pp. 116-117; Haque 2006).

Researchers also argue that transplanted reforms fail because they do not account for the distinctive conditions of the countries in which the transplant is attempted. For example, Gerald Caiden and Pachampet Sundaram have warned reformers to take stock of "shifting combination of history, culture, politics, economics, sociology, ideology and values in each country" (Caiden and Sundaram 2004, p. 373). Similarly, Willy McCourt has cautioned that reforms "gets refracted through the prism of a particular country's laws, cultures, political imperatives and so on" (McCourt 2002, p. 234). Others have emphasized the importance of "unique country-specific contextual factors ... [such as] political history, party politics, macroeconomic considerations, state tradition ... and the state of civil society" (Samaratunge, Alam et al. 2008, p. 25).

Several key "contextual factors" have been identified by students of reform in non-Western countries. Some emphasize the structure of domestic politics and the character and intensity of cleavages within society (Moon and Ingraham 1998; Cheung 2002, p. 246; Sozen and Shaw 2002, p. 483; Haque 2008, p. 28). The influence of "administrative traditions and legacies," and culture and civilizational values, has also been noted (Cheung and Scott 2003; Cheung 2005, p. 273; Bowornwathana 2007; Pillay 2008; Painter and Peters 2010, p. 3; Im, Campbell et al. 2013; Wihantoro, Lowe et al. 2015). Reform may also be stymied by the absence of supporting institutions, such as a robust system for enforcing the rule of law (Hughes 2003, pp. 232-235; Sarker 2006). Finally, imported reforms may fail if they are not compatible with the structure of markets and the overall features of the national economy (Sarker 2006; Xue and Zhong 2012, pp. 288-289).

A third way of explaining the failure of Western reforms in non-Western countries is to emphasize their incompatibility with the overall thinking of leaders about national policy. In the case of South Korea, for example, Tobin Im suggests that imported reforms have succeeded only when they were consistent with the "governing philosophy" of leaders (Im 2017, pp. xvi-xxxviii). In China, according to Xue Lan and Kaibin Zhong, "the vision and judgment of the political leadership is crucial" in determining whether reforms will be implemented (Xue and Zhong 2012, pp. 297-298). From this point of view, the path of institutional reform is not determined directly by the needs or circumstances of Asian countries. What really mat- 
ters is leaders' perceptions of those needs and circumstances, and how their plans take account of them. As Anthony B.L. Cheung puts it: Asian countries have faced strong external pressures to overhaul their institutions, but "reform is still mediated by ... the strategies of the governing elites" (Cheung 2002, p. 245). The renovation of administrative systems is just one part of the elite's larger plan for addressing political and economic problems (Cheung and Scott 2003, p. 2). ${ }^{1}$

We can make two observations about the criticisms that are made against Western-style reforms in the Asian context. First, critics have a distinctive way of thinking about administrative reform: they have a broader view of the aims and challenges of reform than is typically found in most PM scholarship produced in Western countries. In fact, Asian critics approach the subject as Western critics of PM research would like to do: that is, they are already focused on big questions and large forces. Second, this point of view comes very close to the approach outlined earlier in this paper. We might regard the SFG approach as a framework that is helpful in organizing a substantial amount of existing scholarship about the challenges of reform in the non-Western context.

The SFG approach can also be used to provide a more succinct explanation of how the Western model of public management emerged, and why it encountered resistance outside the Western world. In the 1970s and 1980s, leaders in Western countries devised an overall governance strategy that gave priority to certain problems (such as flagging economic performance and declining trust) that were pressing at that time, and which took certain conditions (territorial integrity, societal stability, a mature economy, and a corruption-free public service) for granted. Leaders then invented a set of institutional innovations to execute that strategy. As Christopher Hood has observed, these innovations were "a response to a set of special social conditions [that prevailed]" in Western countries in the 1970s and 1980s (Hood 1991, p. 7). Eventually, these innovations were fused into a "reform paradigm." At the same time, though, understanding about context was erased. If pressed, PM researchers could explain why certain innovations had emerged at a specific time and place; but there was no explicit and generally shared appreciation that the reform paradigm was merely incidental to a larger strategy for governing. Had the spotlight been put directly on the overall strategy, the contingent character of the reform agenda would have been clear.

1. For further discussion about the importance of leaders' predispositions in the Asian context, see: (Straussman and Zhang 2001, p. 420; Bowornwathana 2004; Caiden and Sundaram 2004, p. 375; Bowornwathana 2005; Cheung 2005, p. 265; Christensen, Lisheng et al. 2008, p. 362) 
The erasure of context — that is, the separation of the reform package from the broader and context-contingent strategy for governing - made it easier to believe that the package could be replicated in non-Western countries. But leaders in those countries had their own priorities, and their own overall plans for pursuing those priorities, which were heavily influenced by their assessment of the distinctive circumstances which they faced. In other words, they had invented their own strategies for governing. These strategies largely guided leaders' attitudes toward Western-style reforms. Foreign innovations that fit with the larger strategy were adopted, and those that did not fit were adjusted or discarded. For example, leaders in China adopted some innovations, such as performance measurement, that are popular in the West and also consistent with their goal of preserving of one-party rule (Jing, Cui et al. 2015). Other Western reforms, such as open-government initiatives and anti-corruption policies, have been modified so that they do not threaten party control (Xiao 2013; Lang 2017). Meanwhile innovations that are largely incompatible with one-party rule — such as rule-of-law reforms - encounter more open hostility (Xue and Zhong 2012). In China, as elsewhere, it is impossible to predict which reforms are likely to be adopted from the West, which amended, and which rejected, without first understanding the overall strategy that is being pursued by national leaders.

\section{COMMONALITY AND DIFFERENCE}

No one can dispute that important progress has been made in PM research over the last forty years. But further progress requires a new approach so that important questions can be explored properly. This new approach, focused on the design and implementation of governance strategies, will allow researchers to examine big questions about the evolution of public institutions in a systematic way. It will also provide a way of accounting for wide variation in national circumstances and priorities.

Readers might wonder whether it is possible to recognize diversity and also build bridges between research communities in Western and non-Western countries. Scholars have often complained that there are two conversations about public administration, one in the West and one in the East (Farazmand 1999, p. 518; Jreisat 2005). It might seem that, by emphasizing variation in national priorities and conditions, we will broaden the gap between these two conversations. Anthony B.L. Cheung goes so far as to say that "there is no such thing as one universal model of public administration that satisfies all national political and cultural situations ... [E] ach public administration system is shaped by its own national tradition and his- 
torical evolution" (Cheung 2013, p. 250). If this is true, is there anything in common for scholars in West and East to talk about?

There certainly is. The shared task is strategy-making: the formulation of plans to achieve national goals, the crafting of institutions to implement those plans, and the continuous overhaul of these arrangements in response to changing conditions. All national leaders must do this, even though there is variation in the circumstances which their plans must accommodate. We can compare the processes by which strategies are made, and by which institutions are built up and torn down. And we can make judgments about the robustness and desirability of strategies that are pursued in different countries and at different moments of time. To do this, we need a new vocabulary, and new methods of research too. But there is little doubt that this sort of macro-research can be done without sacrificing conceptual precision or methodological rigor. And by adding this new approach to its toolkit, PM research will be better prepared to address the large challenges that will governments around the world in coming decades.

\section{REFERENCES}

Barber, M. 2007. Instruction to Deliver. London: Politico.

Barrows, D. 1942. Review of "Grand Strategy". The Annals of the American Academy of Political and Social Science 221: 207-208.

Bell, D. 2015. The China Model: Political Meritocracy and the Limits of Democracy. Princeton, NJ: Princeton University Press.

Bowornwathana, B. 2004. Thaksin's Model of Government Reform. Asian Journal of Political Science 12(1): 135-152.

Bowornwathana, B. 2005. Administrative Reform and Tidal Waves from Regime Shifts. Asia Pacific Journal of Public Administration 27(1): 37-52.

Bowornwathana, B. 2007. Governance Reform Outcomes through Cultural Lens:

Thailand. In K. Schedler and I. Proeller (eds.), Cultural Aspects of Public Management Reform (pp. 275-298). Oxford, JAI Press.

Brands, H. 2014. What Good Is Grand Strategy? Ithaca, NY: Cornell University Press. Brands, H. and Suri, J. 2015. Thinking About History and Foreign Policy. In H. Brands and J. Suri (eds.), The Power of the Past: History and Statecraft (pp. 1-26). Washington, DC, Brookings Institution Press.

Bueno de Mesquita, B. 2003. The Logic of Political Survival. Cambridge, MA: MIT Press. 
Caiden, G. and Sundaram, P. 2004. The Specificity of Public Service Reform. Public Administration and Development 24(5): 373-383.

Campbell, C. and Szablowski, G. 1979. The Superbureaucrats: Structure and Behaviour in Central Agencies. Toronto, Canada: Macmillan.

Cannadine, D. 2014. The Undivided Past: History Beyond Our Differences. London: Penguin Books.

Chang, H. 2008. Bad Samaritans. New York, NY: Bloomsbury Press.

Cheung, A. 2002. The Politics of New Public Management: Some Experience from Reforms in East Asia. In K. McLaughlin, S. Osborne and E. Ferlie (eds.), New Public Management: Current Trends and Future Prospects (pp. 243-273). London: Routledge.

Cheung, A. 2013. Can There Be an Asian Model of Public Administration? Public Administration and Development 33(4): 249-261.

Cheung, A. 2005. The Politics of Administrative Reforms in Asia: Paradigms and Legacies, Paths and Diversities. Governance 18(2): 257-282.

Cheung, A and Scott, I. 2003. Governance and Public Sector Reform in Asia: Paradigm Shifts or Business as Usual? New York: RoutledgeCurzon.

Christensen, T., Lisheng, D., and Painter, M. 2008. Administrative Reform in China's Central Government: How Much "Learning from the West"? International Review of Administrative Sciences 74(3): 351-371.

Crawford, J. 2006. The Creation of States in International Law. New York: Oxford University Press.

Critchley, S. 2001. Continental Philosophy: A Very Short Introduction. New York: Oxford University Press.

De Grazia, A. 1957. The American Way of Government. New York: Wiley.

Dewey, J. 1927. The Public and Its Problems. New York: H. Holt and Company.

Donnelly, J. 2013. Universal Human Rights in Theory and Practice. 3rd ed. Ithaca, NY: Cornell University Press.

Earle, E. 1943. Makers of Modern Strategy. Princeton NJ: Princeton University Press.

Evans, P., Rueschemeyer, D., and Skocpol, T., eds. 1985. Bringing the State Back In. New York, Cambridge University Press.

Executive Office of the President. 2002. National Security Strategy of the United States. Washington, DC, Executive Office of the President.

Farazmand, A. 1999. Globalization and Public Administration. Public Administration Review 59(6): 509-522.

Farazmand, A. 2009. Building Administrative Capacity for the Age of Rapid Globalization. Public Administration Review 69(6): 1007-1020.

Farazmand, A. 2012. The Future of Public Administration: Challenges and Opportuni- 
ties. Administration \& Society 44(4): 487-517.

Fernandez, S. and Rainey, H. 2006. Managing Successful Organizational Change in the Public Sector. Public Administration Review 66(2): 168-176.

Fitzpatrick, J, Goggin, G., Heikkila, T., Klingner, D., Machado, J., and Martell, C. 2011. A New Look at Comparative Public Administration. Public Administration Review 71(6): 821-830.

Friedrich, C. 1940. Public Policy and the Nature of Administrative Responsibility. In C. J. Friedrich and E. Mason (eds.), Public Policy, 1940 (pp. 3-24). Cambridge, MA: Harvard University Press.

Fukuyama, F. 2011. The Origins of Political Order. New York: Farrar, Straus and Giroux.

Fukuyama, F. 2014. Political Order and Political Decay. New York: Farrar, Straus and Giroux.

Ghani, A. and Lockhart. C. 2008. Fixing Failed States: A Framework for Rebuilding a Fractured World. New York: Oxford University Press.

Giddens, A. 2013. The Nation-State and Violence. Chicester, UK: Wiley.

Goodhart, M. 2011. Democratic Accountability in Global Politics: Norms, Not Agents. The Journal of Politics 73(1): 45-60.

Gore, A. 1993. Creating a Government That Works Better and Costs Less. New York, NY: Times Books.

Gulrajani, N., and Moloney, K. 2012. Globalizing Public Administration: Today’s Research and Tomorrow's Agenda. Public Administration Review 72(1): 78-86.

Hall, J. and Ikenberry, G. 1989. The State. Minneapolis, MN: University of Minnesota Press.

Haque, M. 2002. Globalization, New Political Economy, and Governance: A Third World Viewpoint. Administrative Theory \& Praxis 24(1): 103-124.

Haque, M. 2006. Reinvention in Public Governance in Southeast Asia. International Journal of Organization Theory and Behavior 9(2): 254-280.

Haque, M. 2008. Global Rise of the Neoliberal State and Its Impact on Citizenship. Asian Journal of Social Science 36: 11-34.

Haque, M. and Turner, M. 2013. Knowledge-Building in Asian Public Administration. Public Administration and Development 33(4): 243-248.

Hay, C. and Lister, M. 2006. Introduction: Theories of the State. In C. Hay, D. Lister and D. March (eds.), The State: Theories and Issues (pp. 1-20). New York: Palgrave Macmillan.

Ho, A. and Im, T. 2015. Challenges in Building Effective and Competitive Government in Developing Countries. The American Review of Public Administration 45(3): 263-280. 
Hood, C. 1991. A Public Management for All Seasons? Public Administration 69(1): 3-20.

Hood, C. 1998. The Art of the State. New York, NY, Clarendon Press.

Hou, Y., Ni, A., Poocharoen, O., Yang, K. and Zhao, Z. 2011. The Case for Public Administration with a Global Perspective. Journal of Public Administration Research and Theory 21(suppl 1): i45-i51.

Hughes, O. 2003. Public Management and Administration. 3rd ed. New York: Palgrave Macmillan.

Hult, K. and Walcott, C. 1990. Governing Public Organizations: Politics, Structures, and Institutional Design. Pacific Grove, CA: Brooks/Cole Pub. Co.

Huntington, S. 1968. Political Order in Changing Societies. New Haven, CT: Yale University Press.

Im, T. 2014. Bureaucratic Power and Government Competitiveness. In H.-J. Kwon and M. G. Koo (eds.), The Korean Government and Public Policies in a Development Nexus, Volume 1 (pp. 55-75). Cham, Switzerland: Springer International Publishing.

Im, T. 2016. Public Organizations in Asia. London: Routledge,.

Im, T. 2017. The Experience of Democracy and Bureaucracy in South Korea. United Kingdom: Emerald Publishing.

Im, T, Campbell, J. and Cha, S. 2013. Revisiting Confucian Bureaucracy: Roots of the Korean Government's Culture and Competitiveness. Public Administration and Development 33(4): 286-296.

Jacobs, L. and King, D. 2009. America's Political Crisis: The Unsustainable State in a Time of Unraveling. PS: Political Science and Politics 42(2): 277-285.

Jessop, B. 2016. The State: Past, Present, Future. New York: Polity.

Jing, Y., Cui, Y. and Li, D. 2015. The Politics of Performance Measurement in China. Policy and Society 34(1): 49-61.

Jreisat, J. 2005. Comparative Public Administration Is Back in, Prudently. Public Administration Review 65(2): 231-242.

Juliani, F. and de Oliveira, O. 2016. State of Research on Public Service Management. International Journal of Information Management 36(6, Part A): 1033-1041.

Kennedy, P. 1991. Grand Strategies in War and Peace. New Haven: Yale University Press.

Kettl, D. 2016. Escaping Jurassic Government. Washington, DC: Brookings Institution.

Kissinger, H. 1961. The Necessity for Choice: Prospects of American Foreign Policy. London, Chatto \& Windus.

Kulman, L. 2016. Teaching Common Sense: The Grand Strategy Program at Yale 
University. New Haven, CT: Prospecta Press.

Lang, B. 2017. China's Anti-Graft Campaign and International Anti-Corruption Norms. Crime, Law and Social Change. https://oi.org/10.1007/s10611-0179742-y

Laski, H. 1919. Authority in the Modern State. New Haven, CT: Yale University Press. Lauterpacht, H. 1947. Recognition in International Law. Cambridge, UK: Cambridge University Press.

Lowe, V. 2015. International Law: A Very Short Introduction. Oxford, UK: Oxford University Press.

Lundestad, G. 2017. International Relations since 1945: East, West, North, South. 8th ed. Thousand Oaks, CA: Sage.

Lynn Jr., L. 2006. Public Management: Old and New. New York, NY, Routledge.

Macdonald, D. 2014. Thumper: The Memoirs of the Honourable Donald S. Macdonald. Kingston, Canada, McGill-Queen's University Press.

Mahoney, J. and Thelen, K. (eds). 2010. Explaining Institutional Change: Ambiguity, Agency, and Power. New York, Cambridge University Press.

Mann, T. and Ornstein, N. 2013. It's Even Worse Than It Looks. New York: Basic Books.

March, J. and Olsen, J. 1989. Rediscovering Institutions: The Organizational Basis of Politics. New York: The Free Press.

Maslin, M. 2014. Climate Change: A Very Short Introduction. 3rd ed. Oxford, UK: Oxford University Press.

McCourt, W. 2002. New Public Management in Developing Countries. In K. McLaughlin, S. Osborne and E. Ferlie, (eds.), New Public Management: Current Trends and Future Prospects (pp. 227-242). London, Routledge.

Melosi, M. 2001. Effluent America: Cities, Industry, Energy, and the Environment. Pittsburgh, PA: University of Pittsburgh Press.

Merriam, C. 1944. The Ends of Government. The American Political Science Review 38(1): 21-40.

Milevski, L. 2016. The Evolution of Modern Grand Strategic Thought. Oxford, UK: Oxford University Press.

Mills, C. 1999. The Power Elite. New York: Oxford University Press.

Milward, H., Jensen, L., Roberts, A., Dussauge-Laguna, M., Junjan, V., Torenvlied, R., Boin, A., Colebatch, H., Kettl, D. and Durant, R. 2016. Is Public Management Neglecting the State? Governance 29(3): 1-26.

Moon, M. and Ingraham, P. 1998. Shaping Administrative Reform and Governance: An Examination of the Political Nexus Triads in Three Asian Countries. Governance 11(1): 77-100. 
Moynihan, D. 2009. "Our Usable Past": A Historical Contextual Approach to Administrative Values. Public Administration Review 69(5): 813-822.

Neumann, S. 1950. Trends toward Statism in Western Europe. Proceedings of the Academy of Political Science 24(1): 13-23.

Ni, C., Sugimoto, C. and Robbin, R. 2017. Examining the Evolution of the Field of Public Administration through a Bibliometric Analysis of Public administration Review. Public Administration Review 77(4): 496-509.

North, D. 1990. Institutions, Institutional Change, and Economic Performance. New York: Cambridge University Press.

Nye, J. 2011. The Future of Power. New York, PublicAffairs.

Opello, W. and Rosow, S. 2004. The Nation-State and Global Order. 2nd ed. Boulder, CO: Lynne Rienner Publishers.

Painter, J. and Jeffrey, A. 2009. Political Geography: An Introduction to Space and Power. London: Sage Publications.

Painter, M. and Peters, B. 2010. Tradition and Public Administration. London: Palgrave Macmillan.

Pal, L. 2012. Frontiers of Governance: The OECD and Global Public Management Reform. New York: Palgrave Macmillan.

Peters, B. and Pierre, J. 2016. Two Roads to Nowhere: Appraising 30 Years of Public Administration Research. Governance 30(1): 11-16.

Pillay, S. 2008. A Cultural Ecology of New Public Management. International Review of Administrative Sciences 74(3): 373-394.

Pollitt, C. 2008. Time, Policy, Management: Governing with the Past. New York: Oxford University Press.

Pollitt, C. 2015. Wickedness Will Not Wait: Climate Change and Public Management Research. Public Money \& Management 35(3): 181-186.

Pollitt, C. 2016. Losing the Big Picture, and Influence Too. Statecrafting.net. https:// statecrafting.net/losing-the-big-picture-and-losing-influence-too-f4a2d8e57532.

Pollitt, C. and Bouckaert, G. 2011. Public Management Reform: A Comparative Analysis. New York: Oxford University Press.

Porter, R. 1980. Presidential Decision Making. New York: Cambridge University Press.

Raadschelders, J. 2010. Is American Public Administration Detached from Historical Context? American Review of Public Administration 40(3): 235-260.

Roberts, A. 2010. What's Wrong with the Intellectual History of Public Administration. Public Voices 11(2): 10-15.

Roberts, A. 2013. Large Forces: What's Missing in Public Administration. North Charleston, SC, CreateSpace Independent Publishing Platform. 
Roberts, A. 2018. The Aims of Public Administration: Reviving the Classical View. Perspectives on Public Management and Governance 1(1): 1-13.

Samaratunge, R., Alam, Q. and Teicher, J. 2008. The New Public Management Reforms in Asia: A Comparison of South and Southeast Asian Countries. International Review of Administrative Sciences 74(1): 25-46.

Sarker, A. 2006. New Public Management in Developing Countries. International Journal of Public Sector Management 19(2): 180-203.

Schumpeter, J. 1976. Capitalism, Socialism, and Democracy. London: Allen and Unwin.

Shaw, M. 2008. International Law. New York: Cambridge University Press.

Shepherd, G. 2003. Civil Service Reform in Developing Countries: Why Is It Going Badly? Washington, DC: World Bank.

Skocpol, T. 1979. States and Social Revolutions. New York: Cambridge University Press.

Sobel, A. 2013. International Political Economy in Context: Individual Choices, Global Effects. Thousand Oaks, CA: CQ Press.

Sozen, S. and Shaw, I. 2002. The International Applicability of "New" Public Management. International Journal of Public Sector Management 15(6): 475-486.

Spruyt, H. 2009. Global Horizons: An Introduction to International Relations. Toronto, University of Toronto Press.

Straussman, J. and Zhang, M. 2001. Chinese Administrative Reforms in International Perspective. International Journal of Public Sector Management 14(4): 411422.

Trubowitz, P. 2011. Politics and Strategy: Partisan Ambition and American Statecraft. Princeton, NJ: Princeton University Press.

Tummers, L., Olsen, A., Jilke, S. and Grimmelikhuijsen, S. 2016. Introduction to the Virtual Issue on Behavioral Public Administration. Journal of Public Administration Reseach and Theory (Virtual issue): 1-3.

Walker, R. 2011. Globalized Public Management: An Interdisciplinary Design Science? Journal of Public Administration Research and Theory 21(suppl 1): i53i59.

Weber, M. 1946. From Max Weber: Essays in Sociology. New York, Oxford University Press.

White, L. 1939. Introduction to the Study of Public Administration. 2d ed. New York, Macmillan.

Wihantoro, Y., Lowe, A., Cooper, S. and Manochin, M. 2015. Bureaucratic Reform in Post-Asian Crisis Indonesia: The Directorate General of Tax. Critical Perspectives on Accounting 31(September): 44-63. 
Williamson, J. 2000. What Should the World Bank Think About the Washington Consensus? World Bank Research Observer 15(2): 251-264.

Xiao, W. 2013. Freedom of Information Reform in China: Information Flow Analysis. International Review of Administrative Sciences 79(4): 790-808.

Xue, L. and Zhong, K. 2012. Domestic Reform and Global Integration: Public Administration Reform in China over the Last 30 Years. International Review of Administrative Sciences 78(2): 284-304.

Zhao, D. and Hu, W. 2017. Determinants of Public Trust in Government: Empirical Evidence from Urban China. International Review of Administrative Sciences 83(2): 358-377. 